\title{
Article
}

\section{B2B Networking, Renewable Energy, and Sustainability}

\author{
Davood Askarany ${ }^{1, *} \mathbb{0}$, Hassan Yazdifar ${ }^{2, *}$ and Kevin Dow ${ }^{1}$ \\ 1 Department of Accounting \& Finance, Business School, University of Auckland, Auckland 1010, \\ New Zealand; kevin.dow@auckland.ac.nz \\ 2 Department of Accounting \& Finance, Bournemouth University, 89 Holdenhurst Road, \\ Bournemouth BH8 8EB, UK \\ * Correspondence: d.askarany@auckland.ac.nz (D.A.); hyazdifar@bournemouth.ac.uk (H.Y.); \\ Tel.: +64-9-9235785 (D.A.)
}

check for updates

Citation: Askarany, Davood, Hassan Yazdifar, and Kevin Dow. 2021. B2B Networking, Renewable Energy, and Sustainability. Journal of Risk and Financial Management 14: 290. https://doi.org/10.3390/ jrfm14070290

Academic Editor: James M. Hanly

Received: 28 April 2021

Accepted: 21 June 2021

Published: 24 June 2021

Publisher's Note: MDPI stays neutral with regard to jurisdictional claims in published maps and institutional affiliations.

Copyright: (c) 2021 by the authors. Licensee MDPI, Basel, Switzerland. This article is an open access article distributed under the terms and conditions of the Creative Commons Attribution (CC BY) license (https:// creativecommons.org/licenses/by/ $4.0 /)$.

\begin{abstract}
While the benefits and advantages of using renewable energies are remarkable, and their prices have been decreasing dramatically and are expected to fall further, the diffusion and adoption of renewable energies still lag fossil energies. This paper improves our understanding regarding the role of the interrelationship among businesses (as an example of B2B networking amongst parent and subsidiary firms). Furthermore, it demonstrates the way/s that such interrelationships can contribute to the diffusion and adoption of sustainable and energy-efficient technologies. This study describes four diffusion channels in the interrelated firms which can help with promoting and using renewable and sustainable energies. The paper also reports the actual share of each diffusion channel contributing to implementing sustainable energy-efficient technologies in practice. The findings suggest that parent organisations enforce the majority (over 50\%) of sustainable and energy-efficient technologies implemented in a B2B environment. In comparison, inter-subsidiary relationships are responsible for less than $30 \%$ of the implemented sustainable and energy-efficient technologies in organisations. The findings are in line with the forced perspective theory. They could, to some degree, explain the differences in the levels of implementation of sustainable and energy-efficient technologies in practice. These findings can help practitioners prioritise the diffusion channels when they want to facilitate the implementation of new technologies in their organisations. While some organisations may expect a more successful implementation of innovations initiated by subsidiaries than those enforced by parent organisations, the levels of success of the adoption of sustainable and energy-efficient technologies are not examined in this study. Further research is recommended to investigate the extent of association between different diffusion channels and the levels of success in terms of the adoption of innovation. We did not find similar studies to compare the results, which could be one of the limitations of this study.
\end{abstract}

Keywords: B2B networking; diffusion of innovation; renewable energies; energy-efficient and sustainable technologies

\section{Introduction}

According to Schmidt and Sewerin (2018), current societal and environmental changes and complexity demand a rapid and substantial socio-technical transition of renewable energies. Recent studies show that "capacity costs of renewable energies have been decreasing dramatically and are expected to fall further, making them more competitive with fossils" (Helm and Mier 2019, p. 812). That is why recent studies highlight the importance of the diffusion of renewable energies (Fadly and Fontes 2019; Li et al. 2019; Srinivasan 2019; Reddy 2018, Tõnurist 2015). However, there is little knowledge about the way/s that the diffusion of renewable energies is taking place via business-to-business (B2B) networking. This paper investigates the diffusion of sustainable energy-efficient technologies among parent and subsidiary firms, which are neither considered a multi-divisional company nor fully independent. Parent and subsidiary firms are different entities, but 
one or more entity/s (parent/s companies) have some controls (ownership right) over other entity/s (subsidiary companies). They are separate businesses which have some interrelated connections, controls, and networking with each other.

While research has extensively explored the impact of a broad range of contextual factors on the diffusion of innovation (Kim and Srivastava 1998; Rabina 1983; Tellis 2008; Wang et al. 2010; Chana et al. 2010; Askarany 2000, 2003a, 2003b, 2005, 2006a, 2006b, 2006c, 2009a, 2009b, 2010a, 2010b, 2011, 2012a, 2012b, 2014, 2015), there is little knowledge on the association between B2B networking in the interrelated firms and the diffusion of new technologies such as energy-efficient technology in organisations (Pfeiffer and Mulder 2013; Petrusic and Janjic 2021; Wang and Liu 2021; Sweidan 2021). This exploratory study investigates the role of $\mathrm{B} 2 \mathrm{~B}$ networking among parent and subsidiary firms in the diffusion of innovation. It clarifies possible channels that such interrelationships can contribute to the diffusion and adoption of sustainable and energy-efficient technologies. The remainder of this paper is structured as follows. Section 2 presents a literature review on sustainable energy and energy-efficient technologies and the diffusion of innovation as two primary components of the current study. Section 3 explains the selected research methodology. Section 4 presents the findings, and Section 5 reports the conclusions.

\section{Literature Review}

The literature on innovation studies is trying to understand the linkages between B2B networking and the ability of these relationships in contributing to the adoption of innovation (Dewick and Miozzo 2004) in general. This paper is aiming to shed some light on the linkage between the diffusion of specific innovation (sustainable energyefficient technologies) and a particular B2B network setting (parent and subsidiary firms as interrelated groups) and explore possible diffusion channels among interrelated firms (which has not been done before).

According to the literature, the diffusion and adoption of innovation, including sustainable and energy-efficient technologies, often occurs through different mechanisms and channels and involves the participation of various parties in a network (Dewick and Miozzo 2004; Wang and Liu 2021; Sweidan 2021; Shorabeh et al. 2021; Petrusic and Janjic 2021; Chang et al. 2021). The focus on interrelationship diffusion channels is exciting since they are simultaneously embedded in two knowledge contexts: (a) the internal group comprised of the headquarters and other subsidiaries and (b) an external environment of regional or host country firms (Almeida and Phene 2004). Tsoutsos and Stamboulis (2005) examine the impact of developing a successful renewable-oriented policy on the diffusion of renewable energy technologies. The current study extends on Tsoutsos and Stamboulis (2005) investigation. It seeks to determine how the diffusion of renewable energy technologies in organisations can be facilitated via interrelationships among businesses in practice.

The main reason for selecting the diffusion of sustainable and energy-efficient technologies as an innovation in this paper is due to its significant position as one of the contemporary topics that have received considerable attention in the literature during the past decade (Worrell et al. 2001; Flamos et al. 2008; Dewick and Miozzo 2004; Pfeiffer and Mulder 2013; Tõnurist 2015; Stucki 2019; Schmidt and Sewerin 2018; Conti et al. 2018; Chang et al. 2021; Hille et al. 2020; Miremadi et al. 2019; Tolliver et al. 2020). The literature identifies several motivations for the diffusion of sustainable and energy-efficient technologies, such as global warming, energy security, fossil fuel depletion, global pollution, and energy efficiency improvements to reduce $\mathrm{CO}_{2}$ emissions (Worrell et al. 2001). According to Stucki (2019), another reason for investing in energy technologies is a cost-saving and economic pay-off. The literature further considers the need for the diffusion of sustainable and energy-efficient technologies as the key concern for the global community and the enhancement of energy security and supply (Flamos et al. 2008). However, it is unclear how B2B interrelationships can contribute to the adoption and the diffusion of energy-efficient technologies in organisations. 
According to Chen and Delmas (Chen and Delmas 2012, p. 1064), "growing social concerns over the environmental externalities associated with business activities are pushing firms to identify activities that create economic value with less environmental impact and to become more eco-efficient." This statement highlights the importance of the diffusion of sustainable energy and energy-efficient technologies as an alternative for creating more economic value-added energy with less environmental impact. Thus, any study to facilitate the diffusion of energy-efficient technologies in practice is expected to be appreciated by practitioners, businesses, and the whole community. Given the importance of sustainable energy and energy-efficient technologies for businesses and the environment, the following section provides a brief background about them and their diffusion in practice.

Sustainable energy refers to renewable energies that can be used for the needs of the current generation and the needs of future generations (Prindle et al. 2007; Wang and Liu 2021; Sweidan 2021; Shorabeh et al. 2021; Petrusic and Janjic 2021; Ivanovski et al. 2021). In line with the above explanations, sustainable energy may include all renewable energy sources, such as solar energy, bioenergy, wind energy, hydroelectricity, wave power, green energy, and geothermal energy, as well as technologies that could improve energy efficiency (Prindle et al. 2007; Guo et al. 2021; Yano and Cossu 2019; Stucki 2019; Miremadi et al. 2019; Manolis et al. 2019; Fadly and Fontes 2019; Ali et al. 2019).

According to Prindle et al. (2007), energy efficiency and renewable energy are the twin pillars of sustainable energy. In other words, selecting more sustainable energy sources (e.g., solar power, bioenergy, wind energy, hydroelectricity, wave power, green energy, etc.) and implementing more efficient technologies (e.g., using LED technology for monitors, lights, and TV versus transistor and plasma technologies or using microwave technology for heating versus traditional element technology) could create more economic value with less environmental impact. This statement implies that moving towards energy sustainability depends on how energy is used and how the energy source is selected.

While adopting sustainable and energy-efficient technologies is not new (Junichiro Oda et al. 2007; Farooq et al. 2018; Yano and Cossu 2019; Ali et al. 2019; Manolis et al. 2019; Pfeiffer and Mulder 2013; Conti et al. 2018; Costantini et al. 2017), research on the association between B2B networking (in the interrelated firms) and the diffusion of sustainable and energy-efficient technologies in organisations is remarkably sparse. We still do not know the details of different sources of diffusion channels in the interrelated firms that could contribute to the adoption and transfer of energy-efficient technologies in organisations (Dewick and Miozzo 2004; Chang et al. 2021; Tolliver et al. 2020; Salah et al. 2020; Hille et al. 2020). The current study focuses on the interrelationship among parent and subsidiary firms by examining its impact on the diffusion and adoption of sustainable and energy-efficient technologies. In doing so, we need to get help from the diffusion of innovation literature.

Deriving from the diffusion of innovation literature, several studies have investigated the diffusion and adoption of new practices and technologies (Wang et al. 2010; Chana et al. 2010; West and Bogers 2014; Alexy et al. 2013; Slater and Narver 1993; Michaelis and Markham 2017). The general assumption is that the potential adopters may conduct a cost-benefit analysis to select the best option (Rogers 2003). However, the present literature reveals that the assumption of efficient choice for the diffusion of innovation is not always the case, and the diffusion of new technology, including energy-efficient technology, may follow other ideologies such as fad and fashion philosophy (Abrahamson 1991, 1996; Lapsley and Wright 2004) and this will be examined in this paper.

There is an accumulated body of literature on the diffusion of new technology and practices (Yazdifar and Askarany 2012; Askarany and Yazdifar 2012; Kim and Srivastava 1998; Rabina 1983; Trondsen 1996; Tellis 2008; Wang et al. 2010; Chana et al. 2010). Wang et al. (2010) address several theories that could explain the diffusion of innovation in organisations: the theories of transaction cost economics, stakeholder theory, organisational learning theory, institutional theory, and social cost theory. Considering these theories, Abrahamson (1991) developed a conceptual matrix with four perspectives to explain the 
diffusion (or the rejection) of new technologies (such as energy-efficient technology) as follows: 'efficient-choice', 'forced', 'fashion', and 'fad' perspectives. The efficient-choice perspective assumes that most adoptions occur because of the benefits and efficiencies gained through implementation. However, such adoptions may follow a forced perspective if organisations such as governmental bodies (DiMaggio and Powell 1991), a powerful purchaser (Malmi 1999), and headquarters and parent companies (Dossi and Patelli 2008) have sufficient power to dictate which innovations are diffused (Lapsley and Wright 2004). The forced perspective "assumes that adopting organisations face a situation of no choice, and their motives play no role in explaining the diffusion and rejection of innovation" (Malmi 1999, p. 653). The fashion perspective is applied when potential adopters still retain a choice over whether to implement an innovation or not (Lapsley and Wright 2004). It assumes that organisations (e.g., subsidiaries) imitate administrative models endorsed by "fashion-setting organisations" or "fashion setters"—-usually advisers. The fad perspective describes how organisations adopt an innovation from other adopting organisations such as other subsidiaries within the group (instead of fashion setters) to appear legitimate and retain a competitive advantage (Chesbrough and Brunswicker 2014).

The fashion perspective might seem at odds with the diffusion of innovation theory. According to the diffusion of innovation theory, the general assumption is that adopters are sensible and take independent, theoretically effective selections based on the cost and benefit criteria (Rogers 2003). The diffusion of innovation theory might also seem at odds with the institutional theory. According to Elliott and Macpherson, "institutional theory recognises that the practice may be diffused in the pursuit of legitimacy rather than as a rational process." Elliott and Macpherson (2010) further emphasise that central to institutional theory is the shift from rationally driven innovation to the pursuit, adoption, compliance, or imitation of new technologies.

In summary, different theories suggest different means and approaches to the diffusion of new technologies. Nevertheless, the literature still lacks adequate studies on the diffusion and transfer of new technologies in interrelated firms and the ability of these interrelated networks to implement new technologies (Dewick and Miozzo 2004). Thus, it is unclear which theory/s is more appropriate to explain the diffusion of renewable and sustainable technologies through $\mathrm{B} 2 \mathrm{~B}$ networking.

We take a neutral view towards the proposed theories for describing the diffusion of innovation in this paper and expect that potential adopters may have different motivations (and follow different theories) for accepting or rejecting an innovation. We are aiming to explore the possible channels by which renewable and sustainable technologies are diffused in organisations. Thus, we are seeking an answer to the following research question in this paper:

How are sustainable and energy-efficient technologies in parent and subsidiary firms introduced and diffused through B2B networking?

The findings may help us better understand the most influential theory/s, which can explain the diffusion of renewable and sustainable technologies through B2B networking in interrelated firms.

\section{Research Methodology and Findings}

To explore how sustainable and energy-efficient technologies in parent and subsidiary firms are introduced and diffused through B2B networking, we conducted 34 interviews (face to face and over the phone) with the managers of 7 parent and 27 subsidiary firms in Australia.

The interviews show that all interviewees favoured using sustainable and energyefficient technologies and believed that there is a need to facilitate the diffusion of such technologies in practice to cope with the variations in the marketplace, knowledge, rivalry, and client focus. They also discussed the critical role of the B2B relationship among the parent/s and subsidiaries in facilitating such diffusion, especially in sharing their experiences and knowledge about new technologies. The interviewees did not challenge 
the function of parent organisations in bringing change to the subsidiaries but added other influencing features which had received less attention in previous studies. For example, an interviewee argued, "We have gained valuable knowledge and expertise from other subsidiaries." Another mentioned, "We now see the success of collaborative actions between other peer subsidiaries and us and also learning from each other."

Interviewees were asked to identify the number/s of energy-efficient technologies/products and practices they had adopted in their organisations during the past two years and their innovations' source/s.

Twenty-eight interviewees (4 from parent and 24 from subsidiary firms) listed 108 (in total) adoptions of energy-efficient technologies/products and practices (minimum 1 and maximum 8 implementations) and their sources. Thirty-two adoptions were considered 'sustainable' and 76 adoptions as 'energy-efficient technologies'. Given that the difference between 'sustainable' and 'energy-efficient' technologies was not the focus of the current study, we combined the above two categories of innovations for analysing.

Analysing the sources of adopted energy-efficient technologies listed by interviewees, we can identify four types of diffusion channels as follows:

1. The sub-division was asked to use a sustainable and energy-efficient technology by the parent.

2. The sub-division was encouraged to use a sustainable and energy-efficient technology by other sub-divisions in the group.

3. The use of a sustainable and energy-efficient technology was decided jointly by a sub-division and other members of the group.

4. The sub-division decided to use a sustainable and energy-efficient technology without any enforcement or encouragement by other group members.

Table 1 shows the total number of adoptions of energy-efficient technologies/products and practices based on the above four types of diffusion channels.

Table 1. The implementation of sustainable and energy-efficient technology in organisations and their sources.

\begin{tabular}{cccc}
\hline $\begin{array}{c}\text { Methods/Channels of the Diffusion of } \\
\text { Innovations in Group Companies }\end{array}$ & $\begin{array}{c}\text { Number of Adopted } \\
\text { Energy-Efficient Technologies }\end{array}$ & \% of Adoption & Normal Expectation \\
\hline Enforced by the parent organisation & 58 & $53.7 \%$ & $25 \%$ \\
\hline Encouraged by other members of the group & 26 & $24.1 \%$ & $25 \%$ \\
\hline Jointly decided by two or more & 10 & $13 \%$ & $25 \%$ \\
\hline $\begin{array}{c}\text { Decided by a subsidiary with no enforcement or } \\
\text { encouragements from other members in the group }\end{array}$ & 14 & $100 \%$ & $100 \%$ \\
\hline Total & 108 & $25 \%$ & \\
\hline
\end{tabular}

This study did not investigate the degree or the scope of the success of adopting sustainable energy-efficient technologies. The focus was only on the impact of interrelationships on the adoption of the above innovations. Thus, both successful and unsuccessful sustainable energy-efficient technologies were included in the results. We assumed no preference for any of the four diffusion channels revealed in our study and left the conclusions to the actual outcomes. In other words, we wanted to be unbiased towards the four diffusion channels, and that is why we expected equal probability (25\%) for each of the four alternatives.

The classification of the methods/channels of diffusion of innovation through B2B networking in interrelated businesses has not been offered and debated in the existing literature. Thus, these findings can be regarded as an exciting contribution to the literature. The four types of diffusion channels will now be discussed (Figure 1). First, the 'groupwide decision' where parent organisations and divisions decided to adopt innovation (e.g., adopting sustainable and energy-efficient technology) were asked to obey the choice. Second, another division was adopted inside the group (or parent) first, and then other 
divisions took it up by encouragement without any enforcement. Third, two or more subsidiaries (or the parent and the subsidiary/s) jointly decided to adopt an innovation. Moreover, fourth, a subsidiary adopted an innovation without the parent's participation (or other divisions).

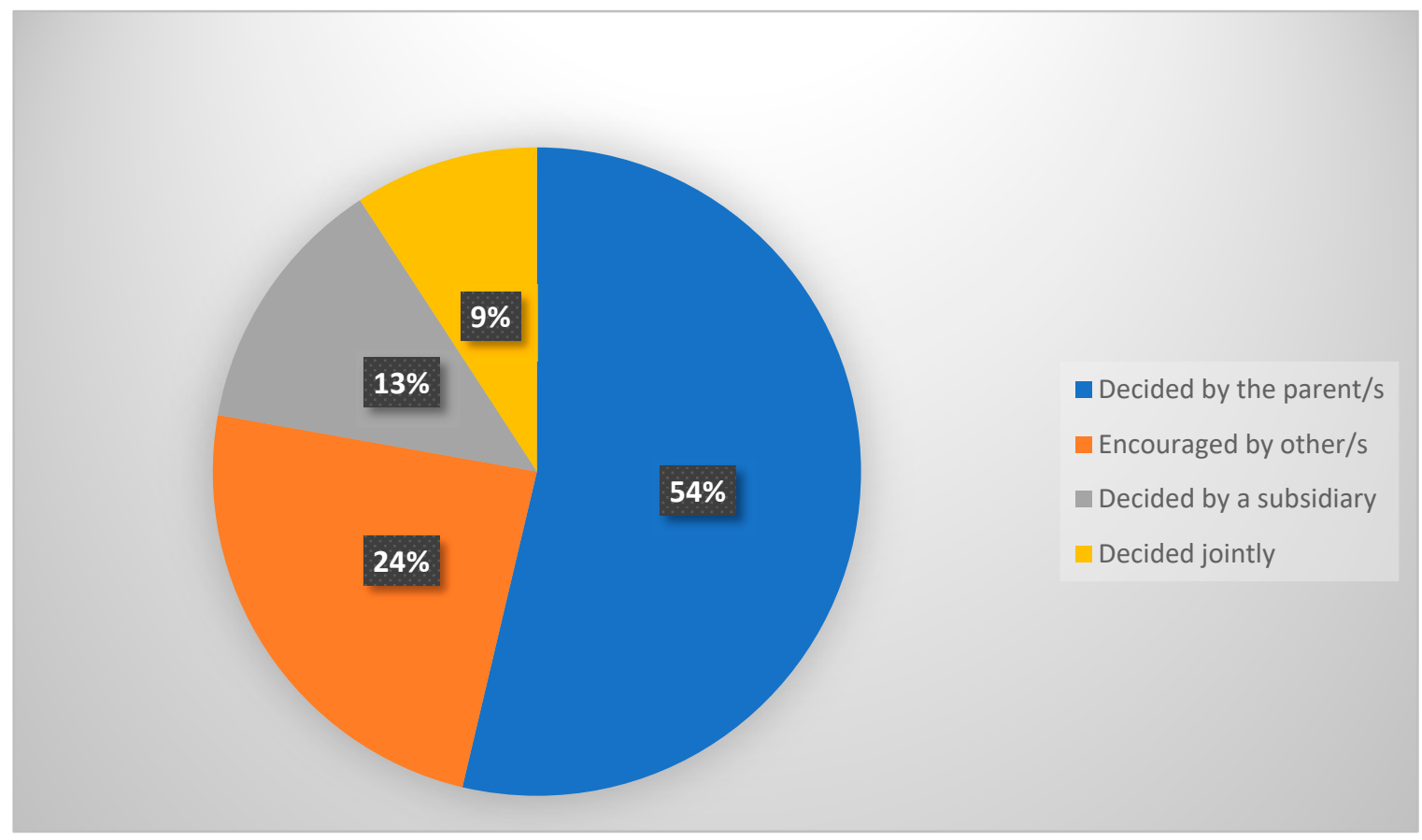

Figure 1. The role of B2B networking in the diffusion of innovations in internal groups.

The discussions in this part may enhance our understanding to recognise which theory/s can better explain the diffusion of sustainable and energy-efficient technologies in B2B settings among interrelated firms. According to our findings, the majority (about 54\%) of the adoptions of sustainable and energy-efficient technologies in organisations had been decided and enforced by parent companies, whereas $13 \%$ were started by a division without the participation of parent organisations (or other divisions). Furthermore, the statistical tests (both $t$-test and chi-square test) show that these adoption rates are significantly (significant at less than $0.05 \%$ ) different. Thus, we may suggest that the extent of the diffusion of sustainable and energy-efficient technologies in organisations decided by parent companies is more significant than those determined by the subsidiary. This trend can be explained by the 'forced perspective' discussed in this paper.

The extant literature has mainly studied the diffusion of innovation in interrelated firms through the first and fourth methods listed above (Dossi and Patelli 2008). However, the second and third ones have not been debated before. There could be some reasons for these sorts of the flow of advances inside interrelated firms. Our study identifies some of them, as debated by the interviewees, as follows. The interviewees explained that in the situation of a shared implementation of innovation or when a division pursues another division in implementing the invention, the divisions might share their understanding around the inventions and the application procedure. This condition reduces the expenses and leads to a more considered understanding of the invention application, which could reduce the ambiguity that happens in the adoption process. In the end, some divisions also argued that a joint implementation could put the subsidiaries in a better situation to challenge the orders imposed by parent organisations. In other words, joint adoption was also a tactic to challenge the institutional pressures of parent companies.

All interviewees were also asked about the advantages and disadvantages of the four diffusion channels. In response to these questions, most interviewees (21 out of 27 
from subsidiary firms) were more supportive of those adoptions initiated by them, jointly adopted with other subsidiaries, or the parent (or learned from them). Two interviewees in subsidiaries commented, "We feel it is easy to learn from a colleague in another subsidiary than from a boss in [the parent organisation]. It gives more confidence when working with a colleague from another subsidiary". "We sometimes get a partial solution from people in the headquarters, but much more and constructive comments from colleagues even in another subsidiary." These interviewees expressed that they had a better understanding of the diffusion of sustainable and energy-efficient technologies, where a sub-division implemented it alone or with the help of another sub-division.

We can highlight the findings of the current paper and link them to Abrahamson's (1991) conceptual matrix with four perspectives (efficient-choice, forced, fashion, and fad perspectives). Our results show that Abrahamson's (1991) four perspectives can lead to the diffusion of innovation in the organisations via the following four diffusion channels observed in the current study as: (1) they are enforced by the parent organisation, (2) encouraged by other members in the group, (3) mutually picked by several subdivisions, (4) selected by a sub-division without any enforcement or encouragements from other members in the group. The first channel of the diffusion innovation observed in our study (enforced by the parent organisation) is more in line with the 'forced' perspective of Abrahamson's (1991) conceptual matrix. In comparison, the other three channels of observed diffusion can be explained by any or a combination of the other three perspectives of Abrahamson's (1991) conceptual matrix (e.g., efficient-choice, fashion, and fad perspectives).

\section{Discussion}

According to the findings, 39\% of respondents were from subsidiaries, while $61 \%$ were from independent organisations. The findings also show that the diffusion of sustainable and energy-efficient technologies in dependent organisations (33.3\%) is relatively higher than independent $(21.3 \%)$ ones. However, the chi-square test $(0.18)$ indicates no significant association between the diffusion of sustainable and energy-efficient technologies in organisations and the types of interrelationships between organisations.

Overall, the findings indicate that almost $87 \%(53.7 \%+24.1 \%+9.2 \%)$ of implemented sustainable and energy-efficient technologies in subsidiaries has been due to the involvement of either parent or other subsidiaries. The remaining $13 \%$ of implementations in sub-divisions was decided individually by sub-divisions. These findings may suggest that some sub-divisions want to leave the responsibilities of taking decisions to parent organisations and follow other subsidiaries. The statistical tests such as the $t$-test and chi-square test only report the adoption rates for sustainable and energy-efficient technologies initiated by the subsidiary and those initiated. However, other diffusion channels within the group (including those initiated by other subsidiaries within the group) are significantly (significant at less than $0.05 \%$ ) different. Thus, we may suggest that the extent of implementing sustainable and energy-efficient technologies in organisations started by other subdivisions within the group is more significant than those decided by the subsidiary itself.

All the interviewees were also asked about their understanding of the diffusion of sustainable and energy-efficient technologies, their advantages and outcomes, difficulties, and limitations. In response to these, the interviewees supported those adoptions initiated by themselves and jointly adopted with other subsidiaries or learnt from them. Two interviewees in subsidiaries commented, "We feel it is easy to learn from a colleague in another subsidiary than from a boss in [the parent organisation]. It gives more confidence when working with a colleague from another subsidiary." "We sometimes get a partial solution from people in the headquarters, but much more and practical comments from colleagues even in another subsidiary." These interviewees expressed that they had a better understanding of the diffusion of sustainable and energy-efficient technologies. The subsidiary adopted them by itself or through another subsidiary but without the parent's involvement. "There is a 'must' with parent's decisions which obstacles smooth learning", 
an interviewee affirmed. In adopting an innovation without parent involvement, the subsidiary's understanding of the new techniques mainly occurred before and during the implementation process. However, this was not like those adopted techniques initiated by parent organisations where the learning about some aspects of the new systems was sometimes postponed post-implementation. "This happens as the adopted approach is hierarchical", an interviewee in a dependent organisation affirmed. Thus, with this, one should expect more successful implementation of the innovation initiated by subsidiaries than those enforced by parent organisations. Further research is recommended to investigate the extent of association between different interrelationship diffusion channels and the levels of success in terms of adopting an innovation.

Using the one-sample $t$-test shows significant differences between the diffusion rates initiated from different channels.

The expected mean is 2.5 based on the following coding:

1. Anchored to the diffusion of sustainable and energy-efficient technology was decided by the parent organisation.

2. Anchored to the diffusion of sustainable and energy-efficient technology was decided by the subsidiary organisation after another subsidiary had implemented it.

3. Anchored to the diffusion of sustainable and energy-efficient technology jointly decided by two or more subsidiaries.

4. Anchored to the diffusion of sustainable and energy-efficient technology was decided by the subsidiary organisation with no previous adoption within the group.

There was a total of 108 adopted innovations initiated from the above four channels. Assuming all adopted innovations were equally initiated from the four above channels, each channel would count for 27 innovations $(108 / 4)$.

The total scores would be $270(1 \times 27+2 \times 27+3 \times 27+4 \times 27)$, producing a mean value of 2.5 (270/108).

According to the Table 2, the actual mean value is 1.81 , which is inclined to the first diffusion channel (parent).

Table 2. One-sample statistics.

\begin{tabular}{|c|c|c|c|c|c|}
\hline \multicolumn{6}{|c|}{ One-Sample Statistics } \\
\hline Diffusion channels & $\begin{array}{c}\mathrm{N} \\
108\end{array}$ & $\begin{array}{c}\text { Mean } \\
1.81\end{array}$ & $\begin{array}{l}\text { Std. Deviation } \\
1.072\end{array}$ & $\begin{array}{c}\text { Std. Error Mean } \\
5.103\end{array}$ & \\
\hline \multirow{4}{*}{ Diffusion channels } & & & & & Test Value $=2.5$ \\
\hline & & & Sig. (2-tailed) & Mean Difference & $95 \%$ Confidence Interval of the Difference \\
\hline & & df & Sig. (2-talled) & Mean Difference & $\begin{array}{ll}\text { Lower } & \text { Upper }\end{array}$ \\
\hline & -6.733 & 107 & 0.000 & -0.694 & $-0.90 \quad-0.49$ \\
\hline \multirow{4}{*}{ Diffusion channels } & & & & & Test Value $=-4$ \\
\hline & & & & & $95 \%$ Confidence Interval of the Difference \\
\hline & $\mathrm{t}$ & $\mathrm{df}$ & Sig. (2-tailed) & Mean Difference & Lower $\quad$ Upper \\
\hline & -21.278 & 107 & 0.000 & -2.194 & -1.99 \\
\hline
\end{tabular}

$>$ The one-sample $t$-test suggests that the adoption rates initiated from different channels are significantly (significant at less than $0.000 \%$ ) different.

$>$ Thus, we can accept our first hypothesis suggesting that the extent of the diffusion of sustainable and energy-efficient technologies in organisations decided by parent companies is more significant than those decided by the subsidiary itself.

$>\quad$ The one-sample $t$-test suggests that the adoption rates initiated by the subsidiary and those initiated through other diffusion channels within the group (including those initiated by other subsidiaries within the group) are significantly (significant at less than $0.001 \%$ ) different. 
$>$ Thus, we can accept our second hypothesis suggesting that the extent of the diffusion of sustainable and energy-efficient technologies in organisations initiated by other subsidiaries within the group is more significant than those decided by the subsidiary itself.

This study is the first to introduce different diffusion channels in group organisations. The findings suggest that the diffusion of sustainable and energy-efficient technologies in subsidiaries is different from parent organisations. For a subsidiary, there are two environments; one being external to the group, and another is the environment formed by the group and other subsidiaries. The subsidiary can adopt a sustainable and energyefficient technology from both sources but with different possibilities. The findings reveal four types of diffusion channels for the implementation and transfer of sustainable and energy-efficient technologies in organisations as follows:

1. The adoption decision is made by the parent organisation.

2. The subsidiary organisation makes the adoption decision after another subsidiary has implemented it.

3. The adoption process is jointly decided by two or more subsidiaries.

4. The adoption decision is made by a subsidiary organisation with no previous adoption within the group.

The study suggests that the majority (over 50\%) of sustainable and energy-efficient technologies are adopted and diffused in group organisations by parent organisations. In comparison, inter-subsidiary relationships form only about $30 \%$ of implemented sustainable and energy-efficient technologies in organisations. The findings align with the forced perspective theory and could provide an excellent example for pursuing and advocating sustainable and energy-efficient technologies in practice. In other words, the findings imply that when the diffusion and the implementation of some sustainable energy resources are not profitable (in terms of cost and benefit analyses) for some particular companies but is appropriate for the society as a whole (e.g., in terms of reducing global pollution and global warming), there should be some enforcement (such as parent company or government regulations) to pursue the diffusion of such innovations in organisations.

According to the findings, $39 \%$ of respondents were from subsidiaries, while $61 \%$ were from independent organisations. The findings also show that the diffusion of sustainable and energy-efficient technologies in dependent organisations (33.3\%) is relatively higher than independent $(21.3 \%)$ ones. However, the chi-square test $(0.018)$ indicates no significant association between the diffusion of sustainable and energy-efficient technologies in organisations and the types of interrelationships between organisations. The findings also suggest that the adoption rates for sustainable and energy-efficient technologies initiated by the subsidiary itself and those initiated through other diffusion channels within the group (including those initiated by other subsidiaries within the group) are significantly (significant at less than $0.05 \%$ ) different, confirming that the extent of the diffusion of sustainable and energy-efficient technologies in organisations initiated by other subsidiaries within the group is more significant than those decided by the subsidiary itself.

However, while the findings suggest that one should expect more successful implementation of the innovation initiated by subsidiaries than those enforced by parent organisations, the success levels of sustainable and energy-efficient technologies are not examined in this study. Therefore, further research is recommended to investigate the extent of association between different diffusion channels and the levels of success in adopting an innovation.

We did not find similar studies to compare the results.

\section{Conclusions}

This study is the first to present the actual evidence of the impact of B2B interrelationships on implementing sustainable energy-efficient technologies in practice. The paper also demonstrates the actual share of each diffusion channel's contribution to the diffusion of sustainable energy-efficient technologies in practice. These findings can help 
practitioners prioritise the diffusion channels when they want to facilitate the diffusion of new technologies in their organisations.

The current study's findings highlight the significant impact of the interrelationship among the businesses on the diffusion of sustainable energy-efficient technologies. The results show that $87 \%$ of the implementation of sustainable energy efficient technologies has been undertaken through three B2B interrelationship channels. Only 13\% of such implementation is decided by the firms (individually) in the groups. This is an essential finding for practitioners to facilitate implementing a particular technology in their organisations. This study did not investigate the degree or scope of implementing sustainable energy-efficient technologies in practice but discovered four diffusion channels contributing to the diffusion of innovation in related groups. Further studies are recommended to seek any possible association/s between success in adopting innovation and each of the four observed diffusion channel/s in the current study. For example, do innovation/s enforced by the parent company have the same degree of success as those decided by the firm?

This paper does not claim that a B2B interrelationship is the only efficient approach for implementing new technologies but provides some practical evidence to demonstrate how B2B interrelationships among businesses can contribute to the implementation of new technologies in an interrelated group via four identifiable diffusion channels.

The study suggests that parent organisations enforce the majority $(54 \%)$ of sustainable and energy-efficient technologies. These findings align with the forced perspective theory and could provide an excellent example for pursuing and advocating sustainable and energyefficient technologies in practice. However, the other three channels (the remaining $46 \%$ of innovations) could be driven by other theories such as efficient choice, fashion choice, transaction cost economics, stakeholder theory, organisational learning theory, institutional theory, and social cost theory.

As with any other investigation, this study is subject to some limitations. The main limitation relates to selecting the targeted population chosen from respondents to a survey questionnaire who had already indicated their willingness for interviews. Furthermore, regarding the small number of interviewees and the considerable variation in terms of different energy-efficient technologies and industries/services, we could not perform further analyses to control these factors. Thus, generalising the results of this study should be done with caution.

Finally, while one may expect a more successful implementation of innovations initiated by subsidiaries than those enforced by parent organisations, the levels of success of the adoption of sustainable and energy-efficient technologies were not examined in this study. Further research is recommended to investigate the extent of association between different diffusion channels and the levels of success in terms of the adoption of innovation. We did not find similar studies to compare the results, which could be one of the limitations of this study. External barriers may be, and are in many instances, very significant hurdles to implementing renewable energies-e.g., vested interests of the fossil fuel industries, legal barriers, and technological lock-ins, which are not discussed in this paper and could be considered for further studies.

Author Contributions: Methodology, H.Y.; writing-original draft preparation, D.A.; writingreview and editing, D.A. and K.D. All authors have read and agreed to the published version of the manuscript.

Funding: This research received no external funding.

Institutional Review Board Statement: No Institutional Review Board Statement was needed for this study.

Informed Consent Statement: Not applicable.

Data Availability Statement: The information used for this study is confidential and we are not allowed to reveal them. 
Conflicts of Interest: The authors declare no conflict of interest.

\section{References}

Abrahamson, Eric. 1991. Managerial Fads and Fashions: The Diffusion and Rejection of Innovations. Academy of Management Review 16: 586-612. [CrossRef]

Abrahamson, Eric. 1996. Management fashion. Academy of Management Review 21: 254-85. [CrossRef]

Alexy, Oliver, Gerard George, and Ammon Salter. 2013. Cui bono? The selective revealing of knowledge and its implications for innovative activity. Academy of Management Review 38: 270-91. [CrossRef]

Ali, Ghaffar, Ningyu Yan, Jafar Hussain, Lilai Xu, Yunfeng Huang, Su Xu, and Shenghui Cui. 2019. Quantitative assessment of energy conservation and renewable energy awareness among variant urban communities of Xiamen, China. Renewable and Sustainable Energy Reviews 109: 230-38. [CrossRef]

Almeida, Paul, and Anupama Phene. 2004. Subsidiaries and knowledge creation: The influence of the MNC and host country on innovation. Strategic Management Journal 25: 847-64. [CrossRef]

Askarany, Davood, and Hassan Yazdifar. 2012. An Investigation into the Mixed Reported Adoption Rates for ABC: Evidence from Australia, New Zealand and the UK. International Journal of Production Economics 135: 430-39. [CrossRef]

Askarany, Davood. 2000. Impact of influencing factors on diffusion of cost and management accounting innovations. Paper presented at Sixth Interdisciplinary Perspectives on Accounting Conference (IPA) Colloquium, Manchester, UK, July 10-12.

Askarany, Davood. 2003a. An Investigation into the Diffusion of Management Accounting Innovations. Ph.D. thesis, University of South Australia, Adelaide, Australia; p. 343.

Askarany, Davood. 2003b. An Overview of the Diffusion of Advanced Techniques. In Advanced Topics in Global Information. Edited by Felix Tan. London: IDEA Group Publishing, pp. 225-50.

Askarany, Davood. 2005. Diffusion of Innovations in Organizations. In Encyclopedia of Information Science and Technology. Edited by Mehdi. Khosrow-Pour. Hershey: IDEA Group Publishing, pp. 853-57.

Askarany, Davood. 2006a. The relationship between characteristics of organisations and implementation of balanced scorecard. Paper presented at 2nd Australasian Business and Behavioural Sciences Association (ABBAS), Adelaide, Australia, September 29-October 3.

Askarany, Davood. 2006b. Technological innovations, activity based costing and satisfaction. Paper presented at 14th Annual Conference on PBFEA, Taipei, Taiwan, July 14-15.

Askarany, Davood. 2006c. Characteristics of adopters and organizational changes. Thunderbird International Business Review 48: 705-25. [CrossRef]

Askarany, Davood. 2009a. An Investigation into the Adoption of Accounting Changes. In Sustaining Competitiveness in a Liberalized Economy: The Role of Accounting. Edited by Ruhanita Maelah. Newcastle: Cambridge Scholars Publishing, pp. 36-53.

Askarany, Davood. 2009b. Innovation Generation and Innovation Adoption. In Encyclopedia of Information Science and Technology. Edited by Mehdi Khosrow-Pour. Hershey: IDEA Group Publishing, pp. 2048-54.

Askarany, Davood. 2010a. A comparative study of the adoption and implementation of target costing in the UK. Paper presented at 3rd International Accounting Conference, Bali, Indonesia, October 25-28.

Askarany, Davood. 2010b. The adoption of managerial tools and organisational satisfaction: Evidence from New Zealand. Paper presented at 22nd Asian-Pacific Conference on International Accounting Issues, Gold Coast, Australia, November 7-9.

Askarany, Davood. 2011. Factors affecting organizational performance. Paradigms 5: 14-31. [CrossRef]

Askarany, Davood. 2012a. Organisational factors and the adoption of benchmarking. Paper presented at 2012 Eurasia Business and Economics Society (EBES) EBES 2012 Conference, Antalya, Turkey, January 13-16.

Askarany, Davood. 2012b. Management Accounting Techniques in the 21st Century. Chisinau: Lambert Academic Publishing.

Askarany, Davood. 2014. Characteristics of innovation and the diffusion of benchmarking. Problems and Perspectives in Management 12: 563-72.

Askarany, Davood. 2015. Innovation of Management Accounting Practices and Techniques. In Encyclopedia of Information Science and Technology. Edited by Mehdi Khosrow-Pour. Hershey: IDEA Group Publishing, pp. 10-19.

Chana, Hing Kai, Shizhao Yina, and Felix Chan. 2010. Implementing just-in-time philosophy to reverse logistics systems: A review. International Journal of Production Research 48: 6293-313. [CrossRef]

Chang, Victor, Yian Chen, Zuopeng Zhang, Qianwen Ariel Xu, Patricia Baudier, and Ben S. C. Liu. 2021. The market challenge of wind turbine industry-renewable energy in PR China and Germany. Technological Forecasting and Social Change 166: 120631. [CrossRef]

Chen, Chien-Ming, and Magali Delmas. 2012. Measuring Eco-Inefficiency: A New Frontier Approach. Operations Research 60: $1064-79$. [CrossRef]

Chesbrough, Henry, and Sabine Brunswicker. 2014. A Fad or a Phenomenon?: The Adoption of Open Innovation Practices in Large Firms. Research-Technology Management 57: 16-25. [CrossRef]

Conti, Chiara, Maria Luisa Mancusi, Francesca Sanna-Randaccio, Roberta Sestini, and Elena Verdolini. 2018. Transition towards a green economy in Europe: Innovation and knowledge integration in the renewable energy sector. Research Policy 47: 1996-2009. [CrossRef]

Costantini, Valeria, Francesco Crespi, and Alessandro Palma. 2017. Characterizing the policy mix and its impact on eco-innovation: A patent analysis of energy-efficient technologies. Research Policy 46: 799-819. [CrossRef] 
Dewick, Paul, and Marcela Miozzo. 2004. Networks and innovation: Sustainable technologies in Scottish social housing. RED Management 34: 323-33. [CrossRef]

DiMaggio, Paul, and Walter Powell. 1991. The New Institutionalism in Organisational Analysis. Chicago: The University of Chicago press.

Dossi, Andrea, and Lorenzo Patelli. 2008. The decision-influencing use of performance measurement systems in relationships between headquarters and subsidiaries. Management Accounting Research 19: 126-48. [CrossRef]

Elliott, Dominic, and Allan Macpherson. 2010. Policy and Practice: Recursive Learning from Crisis. Group E Organization Management 35: 572-605.

Fadly, Dalia, and Francisco Fontes. 2019. Geographical proximity and renewable energy diffusion: An empirical approach. Energy Policy 129: 422-35. [CrossRef]

Farooq, Muhammad, Muhammad Asim, Muhammad Imran, Shahid Imran, Jameel Ahmad, and Muhammad Rizwan Younis. 2018. Mapping past, current and future energy research trend in Pakistan: A scientometric assessment. Scientometrics 117: 1733-53. [CrossRef]

Flamos, Alan, Wong Gaast, Heng Doukas, and George Deng. 2008. EU and Asian countries policies and programmes for the diffusion of sustainable energy technologies. Asia Europe Journal 6: 261-76. [CrossRef]

Guo, Zhongjie, Wei Wei, Maochun Wang, J. Li, Shaowei Huang, Laijun Chen, and Sheng-Wei Mei. 2021. Characterizing and Visualizing the Impact of Energy Storage on Renewable Energy Curtailment in Bulk Power Systems. Applied Sciences 11: 1135. [CrossRef]

Helm, Carsten, and Mathias Mier. 2019. On the efficient market diffusion of intermittent renewable energies. Energy Economics 80: 812-30. [CrossRef]

Hille, Erik, Wilhelm Althammer, and Henning Diederich. 2020. Environmental regulation and innovation in renewable energy technologies: Does the policy instrument matter? Technological Forecasting and Social Change 153: 119921. [CrossRef]

Ivanovski, Kris, Abebe Hailemariam, and Russell Smyth. 2021. The effect of renewable and non-renewable energy consumption on economic growth: Non-parametric evidence. Journal of Cleaner Production 286: 124956. [CrossRef]

Junichiro Oda, J., K. Akimotoa, F. Sanoa, and Toshimasa Tomoda. 2007. Diffusion of energy efficient technologies and $\mathrm{CO}_{2}$ emission reductions in iron and steel sector. Energy Economics 29: 868-88.

Kim, Namwoon, and Rajendra Srivastava. 1998. Managing Intraorganizational Diffusion of Technological Innovations. Industrial Marketing Management 27: 229-46. [CrossRef]

Lapsley, Irvine, and Elisa Wright. 2004. The diffusion of management accounting innovations in the public sector: A research agenda. Management Accounting Research 15: 355-74. [CrossRef]

Li, Jingjing, Jianling Jiao, and Yunshu Tang. 2019. An evolutionary analysis on the effect of government policies on electric vehicle diffusion in complex network. Energy Policy 129: 1-12. [CrossRef]

Malmi, Teemu. 1999. Activity-based costing diffusion across organizations: An exploratory empirical analysis of Finnish firms. Accounting Organizations and Society 24: 649-72. [CrossRef]

Manolis, Enold, Theocharis Zagas, George Karetsos, and Charikleia Poravou. 2019. Ecological restrictions in forest biomass extraction for a sustainable renewable energy production. Renewable and Sustainable Energy Reviews 110: 290-97. [CrossRef]

Michaelis, Timothy, and Stephen Markham. 2017. Innovation Training. Research-Technology Management 60: 36-42. [CrossRef]

Miremadi, Iman, Yadollah Saboohi, and Mohammad Reza Arasti. 2019. The influence of public R\&D and knowledge spillovers on the development of renewable energy sources: The case of the Nordic countries. Technological Forecasting and Social Change 146: 450-63. [CrossRef]

Petrusic, Andrija, and Aleksandar Janjic. 2021. Renewable Energy Tracking and Optimization in a Hybrid Electric Vehicle Charging Station. Applied Sciences 11: 245. [CrossRef]

Pfeiffer, Birte, and Peter Mulder. 2013. Explaining the diffusion of renewable energy technology in developing countries. Energy Economics 40: 285-96. [CrossRef]

Prindle, Bill, Maggie Eldridge, Mike Eckhardt, and Alyssa Frederick. 2007. The Twin Pillars of Sustainable Energy: Synergies between Energy Efficiency and Renewable Energy Technology and Policy. Washington, DC: American Council for an Energy-Efficient Economy and American Council on Renewable Energy.

Rabina, S. 1983. Influencing the Adoption of an Innovation. Industrial Marketing Management 12: 233-41. [CrossRef]

Reddy, Sudhakara. 2018. Economic dynamics and technology diffusion in indian power sector. Energy Policy 120: 425-35. [CrossRef]

Rogers, Everett. 2003. Diffusion of Innovations. New York: Free Press.

Salah, Wael A., Mai Abuhelwa, and Mohammed J. K. Bashir. 2020. The key role of sustainable renewable energy technologies in facing shortage of energy supplies in Palestine: Current practice and future potential. Journal of Cleaner Production 293: 125348. [CrossRef]

Schmidt, Tobias S., and Sebastian Sewerin. 2018. Measuring the temporal dynamics of policy mixes-An empirical analysis of renewable energy policy mixes' balance and design features in nine countries. Research Policy 48: 103557. [CrossRef]

Shorabeh, Saman Nadizadeh, Meysam Argany, Javad Rabiei, Hamzeh Karimi Firozjaei, and Omid Nematollahi. 2021. Potential assessment of multi-renewable energy farms establishment using spatial multi-criteria decision analysis: A case study and mapping in Iran. Journal of Cleaner Production 259: 126318. [CrossRef]

Slater, Stanley F, and John C Narver. 1993. Product-market strategy and performance: An analysis of the Miles and Snow strategy types. European Journal of Marketing 27: 33-51. [CrossRef] 
Srinivasan, Suchita. 2019. The light at the end of the tunnel: Impact of policy on the global diffusion of fluorescent lamps. Energy Policy 128: 907-18. [CrossRef]

Stucki, Tobias. 2019. Which firms benefit from investments in green energy technologies?-The effect of energy costs. Research Policy 48: 546-55. [CrossRef]

Sweidan, Osama D. 2021. The geopolitical risk effect on the US renewable energy deployment. Journal of Cleaner Production 293: 126189. [CrossRef]

Tellis, Gerard. 2008. Important research questions in technology and innovation. Industrial Marketing Management 37: 629-32. [CrossRef]

Tolliver, Clarence, Alexander Ryota Keeley, and Shunsuke Managi. 2020. Policy targets behind green bonds for renewable energy: Do climate commitments matter? Technological Forecasting and Social Change 157: 120051. [CrossRef]

Tõnurist, Piret. 2015. Framework for analysing the role of state owned enterprises in innovation policy management: The case of energy technologies and Eesti Energia. Technovation 38: 1-14. [CrossRef]

Trondsen, Tor Jarl. 1996. Adopters of a Major Innovation in the Computer Field and Its Potential Use in Marketing. Industrial Marketing Management 25: 567-76. [CrossRef]

Tsoutsos, Theocharis D., and Yeoryios A. Stamboulis. 2005. The sustainable diffusion of renewable energy technologies as an example of an innovation-focused policy. Technovation 25: 753-61. [CrossRef]

Wang, Qiang, and Yi Liu. 2021. India's renewable energy: New insights from multi-regional input output and structural decomposition analysis. Journal of Cleaner Production 283: 124230. [CrossRef]

Wang, William, Michael Heng, and Patrick Chau. 2010. The adoption behaviour of information technology industry in increasing business-to-business integration sophistication. Information Systems Journal 20: 5-24. [CrossRef]

West, Joel, and Marcel Bogers. 2014. Leveraging external sources of innovation: A review of research on open innovation. Journal of Product Innovation Management 31: 814-31. [CrossRef]

Worrell, Ernst, Rene van Berkel, Zhou Fengqi, Christoph Menke, Roberto Schaeffer, and Robert O. Williams. 2001. Technology transfer of energy efficient technologies in industry: A review of trends and policy issues. Energy Policy 29: 29-43. [CrossRef]

Yano, Akira, and Marco Cossu. 2019. Energy sustainable greenhouse crop cultivation using photovoltaic technologies. Renewable and Sustainable Energy Reviews 109: 116-37. [CrossRef]

Yazdifar, Hassan, and Davood Askarany. 2012. A comparative study of the adoption and implementation of target costing in the UK, Australia and New Zealand. International Journal of Production Economics 135: 382-92. [CrossRef] 